\title{
Consolidation recovery of rare/hazardous elements from polluted water by the hydrothermal mineralization process
}

\author{
H. Itoh ${ }^{1}$, R. Sasai ${ }^{2} \&$ T. Itakura ${ }^{1}$ \\ ${ }^{1}$ EcoTopia Science Institute, Nagoya University, Japan \\ ${ }^{2}$ Interdisciplinary Faculty of Science and Engineering, \\ Shimane University, Japan
}

\begin{abstract}
Detoxification of polluted water is required in many fields of industrial or agricultural production processes. Not only removal of rare/hazardous elements, but also the recovery and effective use of such elements is essential to increase the resource circulation efficiency. Recycling technology of rare metals and hazardous elements from polluted water would bring about our clean and environmentally benign society. The hydrothermal mineralization process is one of the best candidate techniques to meet the above demand. In the present work, we investigated the consolidation recovery of rare/hazardous inorganic compounds containing $\mathrm{B}, \mathrm{F}, \mathrm{P}, \mathrm{Cr}, \mathrm{As}, \mathrm{Sb}$, etc. The model wastewaters containing the above elements with various concentrations were treated in autoclave under the hydrothermal temperatures of $100-200^{\circ} \mathrm{C}$ using $\mathrm{Ca}(\mathrm{OH})_{2}$ or $\mathrm{CaCl}_{2}$ as the mineralizer. Corresponding minerals, such as $\mathrm{CaB}_{2} \mathrm{O}_{5} \cdot \mathrm{H}_{2} \mathrm{O}, \mathrm{CaF}_{2}$, $\mathrm{Ca}_{5}\left(\mathrm{PO}_{4}\right)_{3}(\mathrm{OH}), \mathrm{Ca}_{2} \mathrm{CrO}_{4}, \mathrm{Ca}_{5}\left(\mathrm{AsO}_{4}\right)_{3}(\mathrm{OH}), \mathrm{Ca}_{2}\left(\mathrm{Sb}_{2} \mathrm{O}_{7}\right)$, were consolidated and separated by filtration after the treatments. Solid/liquid separation under hydrothermal equilibrium was found to be very effective for increasing the yield of minerals, because the final concentration in liquid is determined by the solubility of the mineral under the hydrothermal condition. As a result, the concentration of every residual element in liquid decreased below the National Effluent Standard of Japan. The recovered minerals can be supplied as raw materials for the refining process of ordinary minerals. Such a geo-mimetic wastewater treatment method will be applied to the detoxification and recovery of many kinds of rare/hazardous elements in wastewater.
\end{abstract}


Keywords: hydrothermal mineralization, rare metals, hazardous elements, wastewater, resource recovery.

\section{Introduction}

Wastewaters discharged from industries and natural waters, including underground and river waters, occasionally contain various kinds of inorganic pollutants exceeding their effluent or environmental standards that are enforced by the law in each country. Some of the oxoanions in polluted waters are known to be stable in a wide range of $\mathrm{pH}$ values and concentrations, as well as having electrode potential, such that the removal of the pollutant is difficult by normal precipitation methods. Typical examples are oxoanions of $\mathrm{B}, \mathrm{F}, \mathrm{P}, \mathrm{Cr}, \mathrm{As}, \mathrm{Sb}$, Mo, W, etc. Detoxification of such hazardous ions is required as the first priority, especially in the case of locally high concentrations that lead to human disease and fish deaths.

On the other hand, these wastewaters and natural waters contain rare or precious elements from the viewpoint of resource circulation. They should be recovered and recycled to increase their circulation efficiency. Rare metals, such as $\mathrm{Ni}, \mathrm{Cr}, \mathrm{Mn}, \mathrm{Co}, \mathrm{W}, \mathrm{Mo}, \mathrm{V}$, are defined as national strategic resources that should be stockpiled in Japan. Other elements, e.g., B, P, F, In, Ga, Nd and Dy, are facing worldwide depletion problems because of increasing demand for electrical, magnetic and advanced engineering materials. Technological innovation is desired to consolidate and collect such precious metals dissolved in industrial wastewaters. It is considered from the above overview that in addition to the removal of hazardous and rare elements in polluted waters, their high purity recovery and effective use should be promoted instead of landfill of the coagulated or adsorbed mixtures. Recycling of rare metals and hazardous elements from polluted water would bring about clean and safe lives, as well as an environmentally benign society.

There are several detoxification methods for wastewaters; (1) coagulation and precipitation, (2) solvent extraction, (3) ion exchange, and (4) membrane separation. However, these traditional techniques possess the disadvantages of secondary solid waste generation and high treatment cost. In order to solve these problems, the authors have developed new recovery technology of rare/hazardous elements from polluted waters by the hydrothermal mineralization process. This treatment process is based on "geo-mimetic technology", which imitates the phenomena occurring in the crust and returns the components in wastes to natural minerals. We can utilize these recycled minerals in the refining process for industrial or agricultural production. The concept of urban mine or artificial mine will become important in future society, especially in natural resources deficient in countries like Japan.

In the present work, we review and discuss our respective data on the hydrothermal mineralization recovery of rare/hazardous elements from polluted waters [1-7]. 


\section{Experimental}

\subsection{Batch-type normal hydrothermal mineralization treatment}

Model wastewaters with various concentrations of $\mathrm{B}(\mathrm{OH})_{4}^{-}, \mathrm{F}^{-}, \mathrm{BF}_{4}^{-}, \mathrm{PO}_{4}{ }^{3-}$, $\mathrm{PO}_{3}{ }^{3-}, \mathrm{PO}_{2}{ }^{3-}, \mathrm{AsO}_{3}{ }^{3-}, \mathrm{AsO}_{4}{ }^{3-}, \mathrm{SbO}_{4}{ }^{3-}$ or $\mathrm{CrO}_{4}{ }^{2-}$ were prepared in distilled and deionized water. These model wastewaters $(30 \mathrm{~mL})$ were sealed with the mineralizer $\mathrm{Ca}(\mathrm{OH})_{2}$ or $\mathrm{CaCl}_{2}$ in a normal autoclave (batch-type apparatus) lined with fluorocarbon resin. Hydrothermal treatment was carried out by leaving the vessel in a dry oven for $1-24 \mathrm{~h}$ at a given temperature in the range of $100-200{ }^{\circ} \mathrm{C}$. After the hydrothermal treatment, the vessel was naturally cooled down for $1 \mathrm{~h}$ or cooled down in an ice bath for $15 \mathrm{~min}$. Precipitates were filtered and collected.

\subsection{In situ sampling-type hydrothermal mineralization treatment}

Hydrothermal mineralization apparatus attached with in situ sampling tube as shown in Figure 1 was used if necessary. In this type of apparatus, the liquidsolid separation under hydrothermal condition was achieved by using a sintered metallic mesh filter. Model wastewaters were sealed in the pressure vessel with mineralizer of $\mathrm{Ca}(\mathrm{OH})_{2}$ or $\mathrm{CaCl}_{2}$ (for chromium treatment only). Temperature adjustment was carried out by using the temperature controller (CHINO Corporation, DZ1000).

\subsection{Analysis}

The precipitates were identified by X-ray diffraction (XRD: RIGAKU, Rint-2500) using $\mathrm{Cu} K \alpha$ radiation. The morphology and elemental distribution of the precipitates were observed by SEM-EDS (JEOL JSM-T20, JED02140). The residual elemental concentration in filtrate after the hydrothermal treatment was

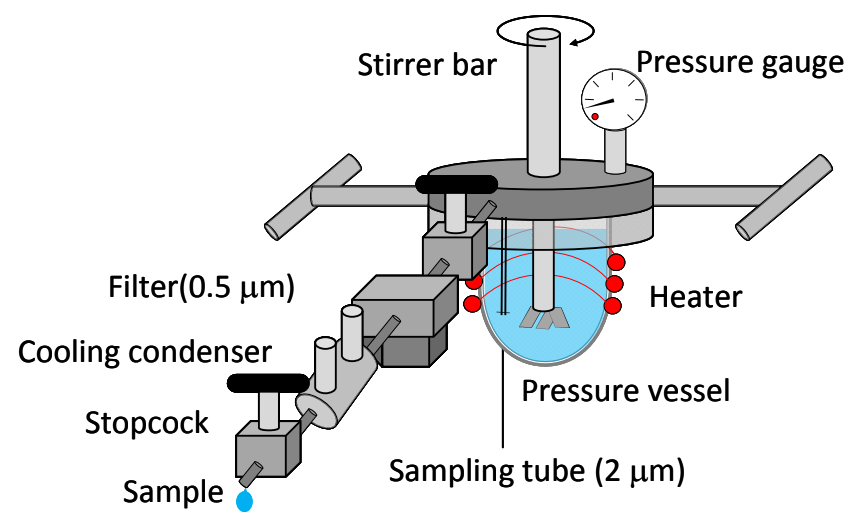

Figure 1: Schematic diagram of in situ separation-type hydrothermal treatment apparatus. 
estimated by inductively couple plasma-atomic emission spectrometry (ICPAES: Perkin-Elmer, Optima3300DV). Concentration of phosphorous ions in the solvent obtained after the hydrothermal treatment was measured by ion chromatograph (IC: Shimadzu, CTO-20AC).

\section{Results and discussion}

\subsection{Recovery of boron or/and fluorine}

Boron containing wastewaters from power stations, plating or glass industries are mostly treated by coagulation-sedimentation method. However, this process needs a large amount of coagulant and has no effective usage of the sludge after the treatment. Improper discharge of the sludge causes the secondary pollution of soils or underground water. Hydrothermal mineralization would be an alternative technique to replace the conventional treatment.

Figure 2 shows the treatment time dependence of residual boron concentration after the hydrothermal treatment in using batch-type apparatus and in situ separation-type apparatus. The starting concentration of boron in model wastewater was $500 \mathrm{mg} / \mathrm{dm}^{3}$ and the added amount of mineralizer $\mathrm{Ca}(\mathrm{OH})_{2}$ was $1 \mathrm{~g}$. The temperature of the autoclave was kept constant at $150^{\circ} \mathrm{C}$. The consolidated product was identified by XRD as $\mathrm{Ca}_{2} \mathrm{~B}_{2} \mathrm{O}_{5} \cdot \mathrm{H}_{2} \mathrm{O}$, which is referred to as Parasibirskite and is one of the starting mineral for borax production. As seen on the plots in figure 2 in case of normal batch-type apparatus, the final concentration of boron cannot meet the value $(10 \mathrm{ppm})$ of National Effluent Standard of Japan (NESJ). However, the residual boron concentration decreased rapidly below $10 \mathrm{ppm}$ over the treatment time of $1 \mathrm{~h}$ by employing the in situ separation-type apparatus. This is because the re-dissolution of the precipitated Parasibirskite can be prohibited by rapid solid/liquid separation before cooling of the solvent. It is considered that the final boron concentration is determined by the low solubility of Parasibirskite near the hydrothermal equilibrium conditions.

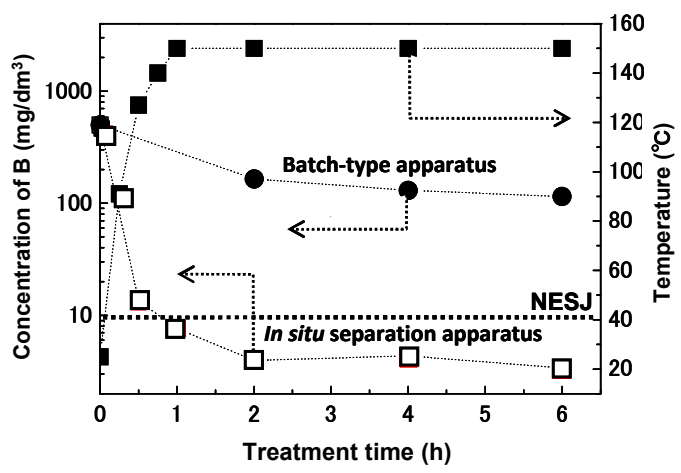

Figure 2: Treatment time dependence of residual boron concentration. $\mathrm{Ca}(\mathrm{OH})_{2}: 1.0 \mathrm{~g}$, treatment temperature: $150^{\circ} \mathrm{C}$, •: batch-type apparatus, $\square$ : in situ separation-type apparatus. 

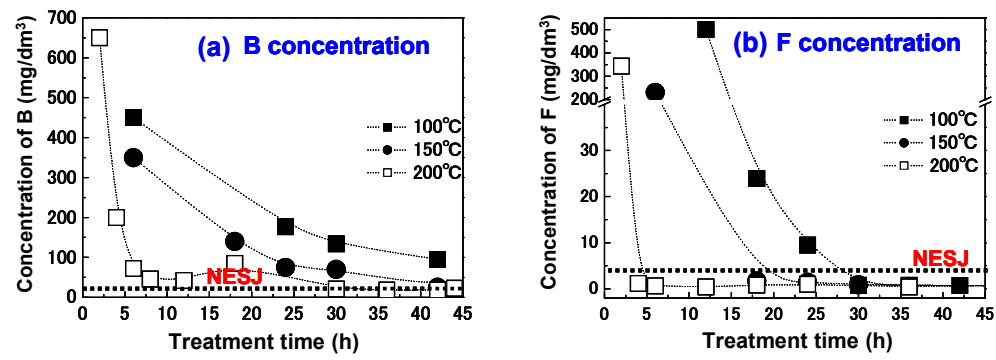

Figure 3: Treatment time dependence of residual (a) boron and (b) fluorine concentrations. $\mathrm{BF}_{4}^{-}: 8000$ ppm, $\mathrm{Ca}(\mathrm{OH})_{2}: 1.0 \mathrm{~g}$, batch-type apparatus.

In many cases of industrial wastewaters, fluorine coexists with boron to form so stable ion known as $\mathrm{BF}_{4}^{-}$, that proper removal technique of this ion has not been established. Figure 3 shows the result of batch-type hydrothermal mineralization experiment using the model wastewater containing the concentration of $8,000 \mathrm{ppm}$. It was found that the optimum temperature and treatment time were $200^{\circ} \mathrm{C}$ and $30 \mathrm{~h}$, respectively. The residual concentrations of both boron and fluorine meet the values of NESJ. The precipitates constituted three layers structure; the bottom layer was $\mathrm{Ca}(\mathrm{OH})_{2}$, the upper layer was $\mathrm{Ca}_{2} \mathrm{~B}_{2} \mathrm{O}_{5} \cdot \mathrm{H}_{2} \mathrm{O}$, Parasibirskite and the surface layer was $\mathrm{CaF}_{2}$, which were confirmed by XRD analysis and SEM-ESD observation. The three layered sediments are considered to form according to the following reactions:

$$
\begin{gathered}
\mathrm{BF}_{4}^{-} \rightarrow 4 \mathrm{~F}^{-}+\mathrm{B}^{3+} \\
\mathrm{B}^{3+}+4 \mathrm{OH}^{-} \rightarrow \mathrm{B}(\mathrm{OH})_{4}^{-} \\
2 \mathrm{~F}^{-}+\mathrm{Ca}^{2+} \rightarrow \mathrm{CaF}_{2} \\
2 \mathrm{~B}(\mathrm{OH})_{4}^{-}+2 \mathrm{Ca}(\mathrm{OH})_{2} \rightarrow \mathrm{Ca}_{2} \mathrm{~B}_{2} \mathrm{O}_{5} \cdot \mathrm{H}_{2} \mathrm{O}+5 \mathrm{H}_{2} \mathrm{O}
\end{gathered}
$$

The reaction (3) forms fine particles of $\mathrm{CaF}_{2}$ suspending in the liquid phase for long term, while $\mathrm{Ca}_{2} \mathrm{~B}_{2} \mathrm{O}_{5} \cdot \mathrm{H}_{2} \mathrm{O}$ precipitates by direct reaction of $\mathrm{B}(\mathrm{OH})_{4}{ }^{-}$ with solid $\mathrm{Ca}(\mathrm{OH})_{2}$ as shown in the reaction (4).

\subsection{Recovery of arsenic}

Arsenic is known to exist as arsenate (pentavalent) ion, $\mathrm{AsO}_{4}{ }^{3-}$ or arsenite (trivalent) ion, $\mathrm{AsO}_{3}{ }^{3-}$ in wide range of $\mathrm{pH}$ and redox potential values of ground and underground waters. They are extremely toxic against human health and ecology particularly for the arsenite ions, so that WHO sets the strict standards for effluent water $(0.1 \mathrm{ppm})$ and drinking water $(0.01 \mathrm{ppm})$.

Arsenic is one of the important raw materials for electronic industries and Japan imports almost all arsenic resources. On the other hand, arsenic containing wastewaters are discharged from petroleum refining plants or thermal power 


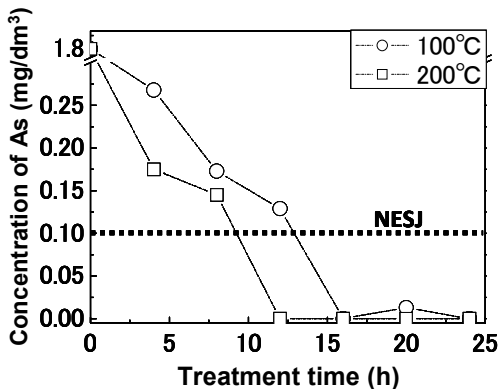

(a)

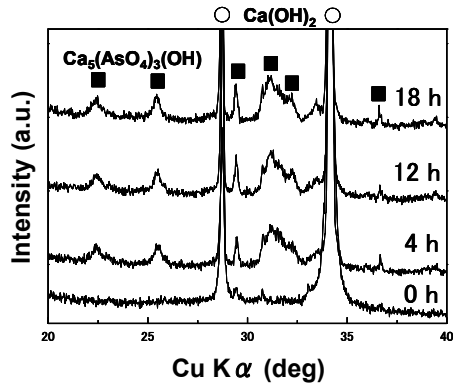

(b)

Figure 4: Hydrothermal mineralization treatment of 2,000 ppm arsenate $\left(\mathrm{As}^{\mathrm{V}} \mathrm{O}_{4}{ }^{3-}\right.$ ) ions. (a) Treatment time dependence of residual arsenate ion concentration. $\mathrm{Ca}(\mathrm{OH})_{2}: 0.36 \mathrm{~g}$, batch-type apparatus. (b) XRD profile of the precipitates obtained at various treatment times.

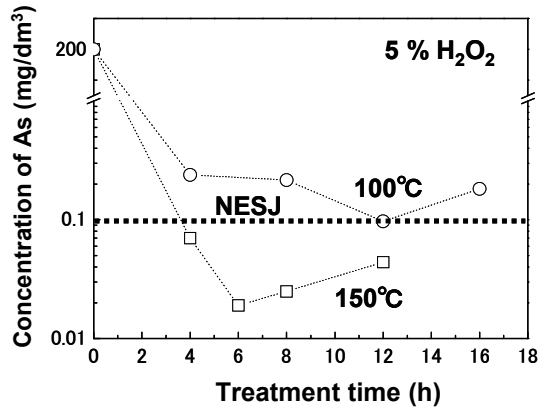

Figure 5: Treatment time dependence of residual arsenic concentration. $\mathrm{As}^{\mathrm{III}} \mathrm{O}_{3}{ }^{3-} 2000$ ppm, $\mathrm{Ca}(\mathrm{OH})_{2}: 0.18 \mathrm{~g}, \mathrm{H}_{2} \mathrm{O}_{2}: 5 \%$, batch-type apparatus.

plants. In addition, serious pollution problems of ground water by arsenic ions occur in Asian countries like Bangladesh, India or China. Therefore, the removal and recycling system of arsenic ions from wastewater or natural waters should be established.

A batch-type hydrothermal mineralization technique was applied to arsenic recovery from model wastewaters containing 2,000 $\mathrm{ppm}^{\mathrm{As}} \mathrm{\textrm {O }}_{4}{ }^{3-}$ ions. Figure 4(a) shows the treatment time dependence of residual arsenate ion concentration at $100^{\circ} \mathrm{C}$ and $200^{\circ} \mathrm{C}$ using normal batch-type apparatus. The concentration of arsenate ion decreases at both temperatures and attain the NESJ requirement of $0.1 \mathrm{ppm}$ over the treatment time of about $15 \mathrm{~h}$. The precipitates were identified as $\mathrm{Ca}_{5}\left(\mathrm{As}^{\mathrm{V}} \mathrm{O}_{4}\right)_{3}(\mathrm{OH})$, Johnbaumite with the same crystal structure of calcium hydroxyapatite, as shown in figure 4(b). 
The detoxification and recovery of trivalent arsenite ion is more difficult according to the conventional absorption, electro-coagulation or membrane permeation methods. Figure 5 shows similar treatment time dependence of arsenic, when $5 \%$ hydroperoxide $\left(\mathrm{H}_{2} \mathrm{O}_{2}\right)$ was added as an oxidizer of arsenite ion. It was found that the concentration of arsenite ion decreased considerably below the NESJ value at $150^{\circ} \mathrm{C}$ for the treatment time of $6 \mathrm{~h}$.

XRD analysis of the precipitates showed that the product was not $\mathrm{Ca}_{5}\left(\mathrm{As}^{\mathrm{III}} \mathrm{O}_{3}\right)_{3}(\mathrm{OH}) \cdot 4 \mathrm{H}_{2} \mathrm{O}$, but $\mathrm{Ca}_{5}\left(\mathrm{As}^{\mathrm{V}} \mathrm{O}_{4}\right)_{3}(\mathrm{OH})$, as shown in figure $4(\mathrm{~b})$. This verifies the oxidation of arsenite (III) ion to arsenate (V) ion. It is concluded that both arsenate and arsenite ions in aqueous media can be consolidated to the arsenic apatite (Johnbaumite) under hydrothermal conditions.

\subsection{Recovery of phosphorus}

Phosphorus that is discharged into surface water from detergents, fertilizers, sewage facilities and printing industries, causes nutrient enrichment and ecological disruption in rivers or lakes. Thus, national effluent standard is set at $16 \mathrm{ppm}$ in Japan. Representative recovery method of pentavalent phosphoric ion $\left(\mathrm{P}^{\mathrm{V}} \mathrm{O}_{4}{ }^{3-}\right)$ is crystallization of magnesium ammonium phosphate (MAP) or hydroxyapatite (HAP) in water. However, phosphorus ions with different oxidation states or forms exist exceptionally in aqueous media in such forms of $\mathrm{P}^{\mathrm{V}} \mathrm{F}_{6}{ }^{-}, \mathrm{P}^{\mathrm{III}} \mathrm{O}_{3}{ }^{3-}$ and $\mathrm{P}^{\mathrm{I}} \mathrm{O}_{2}{ }^{3-}$, used as ionic liquid or Ni-P plating liquid. These ions are known not to form precipitates by the conventional treatment method.

From the viewpoint of raw material supply, phosphorous is industrially important, but is finite resources used for medicines, surfactants, fertilizers, etc. Therefore, phosphorus recovery techniques should be developed regardless of its form or oxidation state. Hydrothermal mineralization recovery was attempted for the phosphonic ions, $\mathrm{P}^{\mathrm{III}} \mathrm{O}_{3}{ }^{3-}$ and phosphinic ions, $\mathrm{P}^{\mathrm{I}} \mathrm{O}_{2}{ }^{3-}$.
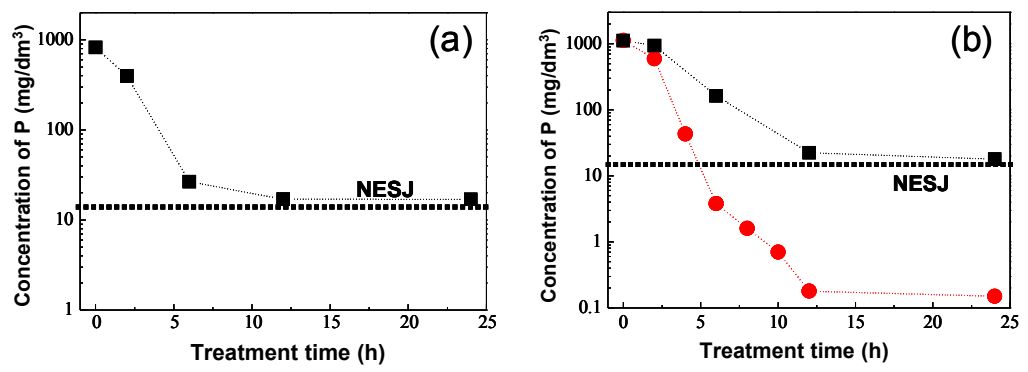

Figure 6: Treatment time dependence of residual phosphorus concentration. Model wastewater: mixture of $1,000 \mathrm{ppm} \mathrm{P}^{\mathrm{III}} \mathrm{O}_{3}{ }^{3-}$ and 1,000 ppm $\mathrm{P}^{\mathrm{I}} \mathrm{O}_{2}{ }^{3-}$. (a) $200^{\circ} \mathrm{C}, \mathrm{Ca}(\mathrm{OH})_{2}: 0.50 \mathrm{~g}, \mathrm{H}_{2} \mathrm{O}_{2}: 1 \%$, batch-type apparatus, (b) $200^{\circ} \mathrm{C}, \mathrm{Ca}(\mathrm{OH})_{2}: 1.0 \mathrm{~g}, \mathrm{H}_{2} \mathrm{O}_{2}$ \% apparatus, $\bullet$ : in-situ separation-type apparatus. 
Figure 6 shows the treatment time dependence of residual phosphorus concentration at $200^{\circ} \mathrm{C}$ in using the mixed model wastewaters of $1,000 \mathrm{ppm}$ $\mathrm{P}^{\mathrm{III}} \mathrm{O}_{3}{ }^{3-}$ and $1,000 \mathrm{ppm} \mathrm{P}^{\mathrm{I}} \mathrm{O}_{2}{ }^{3-}$. Figure 6(a) is the data by batch-type apparatus, when $1 \%$ of oxidizer $\mathrm{H}_{2} \mathrm{O}_{2}$ was added to increase the oxidation number of phosphonic or phosphinic ions in a similar way to arsenic case. The concentration of $\mathrm{P}$ decreased compared with the case with no $\mathrm{H}_{2} \mathrm{O}_{2}$ addition. However, it cannot meet the NESJ value. In contrast, the $\mathrm{P}$ concentration decreased below the NESJ in using in-situ separation-type apparatus even without $\mathrm{H}_{2} \mathrm{O}_{2}$ addition, as indicated in Figure 6(b). The precipitate was identified as $\mathrm{Ca}\left(\mathrm{HPO}_{3}\right)\left(\mathrm{H}_{2} \mathrm{O}\right)$.

\subsection{Recovery of chromium}

Chromium exists as hexavalent and trivalent ions in a wide range of $\mathrm{pH}$ values and concentrations at normal pressure and temperature. However, most chromium ion in wastewater from electroplating or metal finishing industries is hexavalent. Its toxicity is higher than that of trivalent $\mathrm{Cr}$, so that reduction of $\mathrm{Cr}$ (VI) to $\mathrm{Cr}$ (III) is needed before/after the conventional treatment by adsorption, reverse osmosis, ion exchange or chemical precipitation technique. Hydrothermal mineralization treatment was carried out to detoxify and recover chromium as recyclable solids.

$\mathrm{CaCl}_{2}$ was chosen as mineralizer instead of $\mathrm{Ca}(\mathrm{OH})_{2}$ in this experiment in order to increase the solubility of calcium salts under hydrothermal conditions. Figure 7 shows the effect of the added amount of $\mathrm{CaCl}_{2}$ on the residual concentration of $\mathrm{Cr}$, when the model wastewater with $2,000 \mathrm{ppm} \mathrm{Cr}^{\mathrm{VI}} \mathrm{O}_{4}{ }^{2-}$ was treated at $200^{\circ} \mathrm{C}$ for $2 \mathrm{~h}$ using the in-situ separation-type apparatus. The residual chromium concentration reduced with an increase in $\mathrm{CaCl}_{2}$ added, which suggests that the equilibrium in liquid phase will shift to the forward formation reaction of $\mathrm{CaCrO}_{4}$ precipitates by increasing the $\mathrm{CaCl}_{2}$ content in liquid phase. At the added amount of $0.68 \mathrm{~g} \mathrm{CaCl}_{2}, \mathrm{Cr}$ (VI) concentration was $0.48 \mathrm{ppm}$, which was below the NESJ value $(0.5 \mathrm{ppm})$.

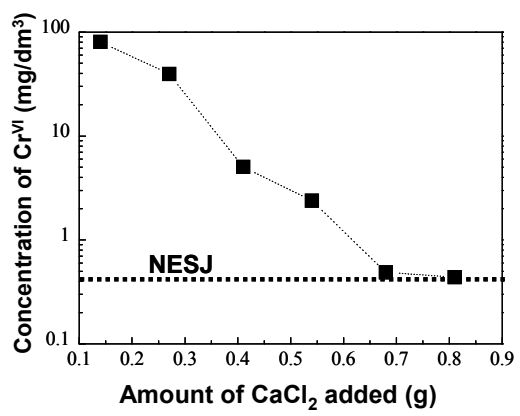

Figure 7: Concentration of $\mathrm{Cr}$ as a function of the added amount of mineralizer $\mathrm{CaCl}_{2}$. Treatment temperature: $200^{\circ} \mathrm{C}$, treatment time: $2 \mathrm{~h}$, in-situ separation-type apparatus. 
Figure 8 shows the effect of initial concentration of $\mathrm{Cr}$ (VI) ion on the residual concentration of $\mathrm{Cr}$ (VI), when treated at $200^{\circ} \mathrm{C}$ for $2 \mathrm{~h}$ with $0.68 \mathrm{~g}$ $\mathrm{CaCl}_{2}$ added by using in-situ separation-type apparatus. It is evident that the residual concentration of chromium is independent of the initial concentration of $\mathrm{Cr}$ (VI) in the range of 20 to $200 \mathrm{mg} / \mathrm{dm}^{3}$. The average concentration is found as low as about $0.5 \mathrm{ppm}$, which is determined only by the solubility of $\mathrm{CaCrO}_{4}$ under hydrothermal equilibrium. This verifies a wide applicability of hydrothermal mineralization technique for polluted water by chromium.

\section{Summary}

It was clarified from the above experiments that rare/hazardous elements $(\mathrm{B}, \mathrm{F}$, $\mathrm{P}, \mathrm{As}, \mathrm{Cr}$ ) were recovered from various kinds of polluted waters by hydrothermal mineralization process, and their detoxification and purification were accomplished in every case below the NSEJ values. Table 1 shows the summarized list on applicable ions, final concentrations and recovered minerals. The data of $\mathrm{Sb}$ recovery is added in the table though details are not described

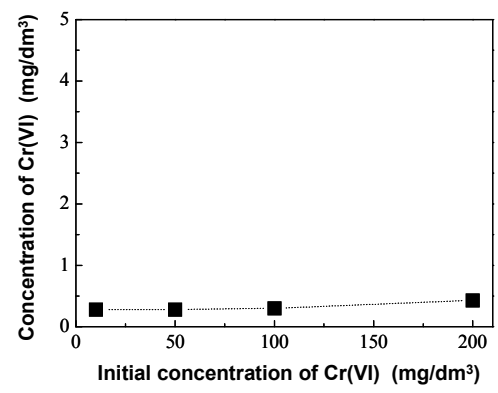

Figure 8: Concentration of $\mathrm{Cr}$ as a function of initial concentration of $\mathrm{Cr}$. Treatment temperature: $200^{\circ} \mathrm{C}$, treatment time: $2 \mathrm{~h}$, in-situ separation-type apparatus.

Table 1: Applicable starting ions, final concentrations and recovered minerals treated by hydrothermal mineralization.

\begin{tabular}{|c|c|c|c|c|c|c|c|}
\hline & $\mathrm{B}(\mathrm{OH})_{4}^{-}$ & $\mathrm{F}^{-}$ & $\mathrm{BF}_{4}^{-}$ & 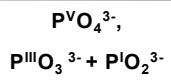 & $\mathrm{As}{ }^{\mathrm{III}} \mathrm{O}_{3}{ }^{3-}, \mathrm{As}^{\mathrm{V}} \mathrm{O}_{4}{ }^{3-}$ & $\mathrm{Sb}^{\mathrm{V}} \mathrm{O}_{4}{ }^{3-}$ & $\mathrm{Cr}^{\mathrm{VI}} \mathrm{O}_{4}{ }^{2-}$ \\
\hline $\begin{array}{l}\text { Conc. after } \\
\text { the treatment } \\
\left({ }^{*} \mathrm{NESJ}\right) / \mathrm{ppm}\end{array}$ & $4(10)$ & $\begin{array}{c}4 \\
(8)\end{array}$ & $\begin{array}{l}F: 4 \\
B: 4\end{array}$ & $\begin{array}{l}\text { N.D. (16) } \\
0.2(16)\end{array}$ & $\begin{array}{l}0.016 \\
(0.1)\end{array}$ & $0.02(0.02)$ & $\begin{array}{l}0.44 \\
(0.5)\end{array}$ \\
\hline $\begin{array}{l}\text { Recovered } \\
\text { minerals }\end{array}$ & \multicolumn{3}{|c|}{$\begin{array}{c}\mathrm{B}: \mathrm{Ca}_{2} \mathrm{~B}_{2} \mathrm{O}_{5} \cdot \mathrm{H}_{2} \mathrm{O} \\
\text { (Parasibirskite) } \\
\mathrm{F}: \mathrm{CaF}_{2} \\
\text { (Fluorite) }\end{array}$} & $\begin{array}{c}\mathrm{Ca}_{5}\left(\mathrm{PO}_{4}\right)_{3}(\mathrm{OH}) \\
\text { (Hydroxyl } \\
\text { apatite) }\end{array}$ & $\begin{array}{l}\mathrm{Ca}_{5}\left(\mathrm{AsO}_{4}\right)_{3}(\mathrm{OH}) \\
\text { (Johnbaumite) }\end{array}$ & $\begin{array}{r}\mathrm{Ca}_{2}\left(\mathrm{Sb}_{2} \mathrm{O}_{7} \text { ) }\right. \\
\text { (Monimolite) }\end{array}$ & $\mathrm{Ca}_{2} \mathrm{CrO}_{4}$ \\
\hline
\end{tabular}

* NESJ: National effluent standard of Japan. 
here. Each calcium mineral is found in natural mine, where it is formed under high temperature and pressure conditions in crust. Therefore, such recovered mineral can be supplied to the refining process as recycled resource.

This technique is based on the principle of negative dissolution enthalpy $\Delta_{\text {sol }} H$ of such minerals in aqueous media. When the temperature of solution is raised from $T_{1}$ to $T_{2},\left(T_{2}>T_{1}\right)$, the equilibrium constant $\left(K_{T 2}\right)$ of dissolution reaction at temperature $T_{2}$, is formulated as follows:

$$
\left.K_{T 2}=K_{T 1} \exp \left(\Delta_{s o l} H\left(T_{2}-T_{1}\right)\right) / \mathrm{R} T_{1} T_{2}\right),
$$

where $\mathrm{R}$ is gas constant. If the dissolution enthalpy is negative, $K_{T 2}<K_{T 1}$, the dissolution reaction proceeds forward by temperature increasing. Calcium minerals with negative dissolution enthalpy are found in other elements such as $\mathrm{Se}, \mathrm{Te}, \mathrm{W}, \mathrm{Mo}$, etc. Hydrothermal mineralization recovery can be applied to these elements dissolved into polluted water. High recovery yield could be expected by using in-situ separation-type apparatus.

\section{References}

[1] Itakura, T., Sasai, R. \& Itoh, H., Precipitation recovery of boron from wastewater by hydrothermal mineralization. Water Research, 39, pp. 25432548, 2005.

[2] Itakura, T., Sasai, R. \& Itoh, H., A novel recovery method for treating wastewater containing fluoride and fluoroboric acid. Bull. Chem. Soc. Jpn., 79(8), pp. 1303-1307, 2006.

[3] Itakura, T., Sasai, R. \& Itoh, H., In site solid/liquid separation effect for high-yield recovery of boron and fluorine from aqueous media containing borate or fluoroborate ions., Bull. Chem. Soc. Jpn., 80(10), pp. 2014-2018, 2007.

[4] Itakura, T., Sasai, R. \& Itoh, H., Arsenic recovery from water containing arsenite and arsenate ions by hydrothermal mineralization. J. Hazardous Materials, 146, pp. 328-333, 2007.

[5] Itakura, T., Imaizumi, H., Sasai, R. \& Itoh, H., Phosphorous mineralization for resource recovery from wastewater using hydrothermal treatment. $J$. Ceram. Soc. Japan, 117(3), pp. 316-319, 2009.

[6] Itakura, T., Imaizumi, H., Sasai, R. \& Itoh, H., Chromium and phosphorous recovery from polluted water by hydrothermal mineralization. Waste Management and the Environment IV, (WIT Press, Southampton, UK), pp. 781-788. 2008.

[7] Itakura, T., Sasai, R. \& Itoh, H., Detoxification of antimonic contaminated water and precipitation recovery of antimony by mineralization under hydrothermal condition. Chemistry Letters, 36(4), pp. 524-525, 2007. 